\title{
EXPERIMENTAL AND NUMERICAL STUDY ON COLUMN-FOUNDATION CONNECTION THROUGH EXTERNAL SOCKET
}

\author{
Haiying MA®1, Minghui $\mathrm{LAI}^{1}$, Xuefei SHI ${ }^{1 *}$, Zhen $\mathrm{CAO}^{2}$, Junyong ZHOU®3 \\ ${ }^{1}$ Department of Bridge Engineering, College of Civil Engineering, Tongji University, 200092 Shanghai, China \\ ${ }^{2}$ Shanghai Architecture and Construction Material Marketing Management Station, 200003 Shanghai, China \\ ${ }^{3}$ College of Civil Engineering, Guangzhou University, 510006 Guangzhou, China
}

Received 24 December 2019; accepted 12 October 2020

\begin{abstract}
In practice, bridge foundations and pier columns are usually constructed with cast-in-place concrete. Precast columns are currently widely used in highway bridges in China, which can save construction time and improve concrete quality. The connection between precast bridge columns and the foundation can affect how forces transfer from one to the other. This paper investigates using external sockets to form a connection between the bridge column and foundation. This method can accelerate the bridge construction time with the additional advantages of improving the orientation and creating a large erection tolerance. Two types of connections are presented and tested to investigate the behavior of the column-foundation connections and find a more suitable way to use external socket connections. The experimental results show that the column-foundation connection design satisfies the design requirements. The results also show that roughening the column surface within the external socket is more effective at connecting the column to the foundation when using an external socket compared to attaching a steel plate on the column. The experimental results are validated with a finite element analysis, resulting in a proposal regarding the column-foundation connection behavior as well as design recommendations for the external socket connection.
\end{abstract}

Keywords: column-foundation connection, service condition, gap, ultimate capacity, load-displacement.

\section{Introduction}

In recent years, precast and prefabrication technologies have been widely used for superstructure projects in China to accelerate the construction time and ensure structure component quality. For bridge substructures, the precast technology is just starting to be applied to bridge columns. Bridge foundations are usually constructed on site with cast-in-place concrete. The use of precast concrete column reduces construction time, improves concrete quality and onsite safety, and enhances the efficiency and construction control (Do et al., 2018; Billington et al., 1999). The cross sections of precast columns can include solid or hollow circular section as well as rectangular sections. The columns can be precast segmentally (Cai et al., 2018; Hung et al., 2017; Li et al., 2017a, 2017b; Xia et al., 2019; Zhao et al., 2017) or integrally (Nguyen et al., 2017). In the past few decades, a number of connection methods have been used to connect precast columns to foundations including grouted sleeve couplers, socket connections, grouted ducts, and hybrid systems. Considerable research has been completed on these connections considering the static and dynamic behavior (Hewes, 2013; Nguyen et al., 2017; Wang et al., 2018).

Grouted sleeve couplers can reduce the congestion of reinforcements, but they require a tight tolerance for erection and expensive proprietary hardware and grout (Belleri \& Riva, 2012; Li et al., 2018; Yan et al., 2018). Belleri and Riva (2012) investigated the behavior and performance of grouted corrugated steel sleeve connections under cyclic loading and developed an experimental study in which the experimental results show that grouted steel sleeves are suitable as column-foundation connections in the seismic regions. Grouted ducts, on the other hand, have inexpensive stay-in-place ducts and acceptable tolerances, but they require complex grouting operations (Marsh et al., 2011). Hewes (2013) finds that the grouted duct system can achieve significant moments. Marsh et al. (2011) showed the grouted duct connection being used with projects located in both non-seismic and seismic re-

${ }^{*}$ Corresponding author. E-mail: shixf@tongji.edu.cn 
gions. The disadvantages include the space requirement in the adjacent member's reinforcement cage.

Socket connections leave a small area between the elements to allow for a closure pour of cast-in-place concrete, and the precast column and foundation are connected by a part of column embedded into the cavity of the foundation (internal socket connection). Canha et al. (2012) developed an experimental study on the behavior of the socket and column as a monolithic connection, and suggested the vertical reinforcement should be designed based on the bending theory. The embedded part of the column is usually precast with a rough interface, which works as a shear key to transfer forces between column and foundation. Socket connections have large construction tolerances and simple grouting operations, and, as a result, this method is often used in non-seismic and low-seismic regions. Hybrid systems use post-tensioned (PT) tendons and mild steel reinforcement or other energy dissipating material to connect column and foundation (Hewes, 2013; Marsh et al., 2011; Wang et al., 2018). The PT tendons remain elastic and render the connection self-centering under lateral cyclic loading, while the bar reinforcements yield alternately to dissipate energy under cyclic loading. Due to the reduced residual drift, the seismic performance is potentially much better than other connection methods. But, at the same time, this method carries much greater construction risk since the post-tension tendons require special construction control. Tran (2015) proposed a drilled shaft socket connection for precast columns for moderate or high seismic regions, and conducted quasi-static tests to investigate the seismic performance. The research showed that the conventional amount of shaft spiral protected the shaft while the precast column with a plastic hinging failed. Tazarv and Saiidi (2015) developed pocket connection design methods to assemble precast columns and precast cap beams, and proposed design guidelines for precast bent caps incorporating pocket connections. The research showed that the pocket depth should be greater than the column side dimension to guarantee that the full plastic moments were developed in columns. Cheng and Sritharan (2019) conducted the tests for a precast member with internal socket, and their research showed that the socket connection could provide significant resistance for side shear to transfer large vertical loads. Wang et al. (2019) conducted tests for precast columns with internal socket and pocket connections. Their research found that the differences between precast columns and cast-in-place columns were within $15 \%$, and the load-displacement curves from numerical results had good agreement with the test results. Cheng and Sritharan (2020) conducted tests for a prefabricated column-pile cap-pile system at service condition and extreme event condition. The results show that the column connection and pile connections exhibited excellent behavior for service condition, and a plastic hinge was induced in the column for extreme event condition.

In view of construction cost, time, and tolerance, the socket connection is more efficient than the other types of connections reviewed above. Recent research on socket connections mostly focuses on the internal socket connection in which the precast column is embedded into the cavity of the foundation. In these cases, the foundation is either cast in place or precast with a void, which requires complicated reinforcements design and cast-in-place concrete template arrangement. Rather than using an internal socket connection, this paper proposes using an external socket to connect the precast column and foundation (either cast-in-place or precast). With an external socket, the foundation does not require a cavity, which makes the foundation design and construction process simpler. The precast column is oriented and put on the foundation, and no reinforcement connects the column bottom and foundation. Similar to the drilled shaft socket connection, the external socket with spirals is erected with cast-in-place concrete to connect the precast column to the foundation. For the drilled shaft socket connection, the reinforcement cage is embedded and connected to the base (foundation). For the external socket, however, no reinforcement is extended into the foundation (or the base). The bottom of the columns within the external socket is precast either with or without a rough surface. The advantages of using an external socket include the simple installation and variable socket size, which is a better choice for longer length bridge projects.

The external socket connections in this paper were designed for and used in a bridge project in Anhui Province, China. The project has a length of $12 \mathrm{~km}$ of three spans, or four spans of continuous girder bridges. The columns are precast with a hollow circular section for all of the bridges, and required accelerated construction with low orientation requirements. The motivations for using external socket connections include four key considerations: (1) the necessary grouting in hollow core precast columns is difficult to complete and connect to the columns and foundation; (2) the precast column is fabricated in a factory, and the templates used for concrete columns cannot initially allow rebars extending from the bottom of the column. As a result, grouted duct connections using rebars are not allowed in the initial design of the project; (3) the total length of the project is long $(12 \mathrm{~km})$, and requires a lot of precast columns to complete the project. This means that the orientation and construction should not take much time and results in fewer construction tolerance requirements; (4) and the bridges are located in the low seismic region (in Anhui Province in China, and low seismic behavior is included in the design), and the seismic requirement doesn't control the socket connection design.

In this paper, two types of external socket connections are presented and investigated to find a more suitable way to use external socket (see Figure 1). An experimental study is developed to investigate the behavior of the column-foundation connections and validate the design of the external socket connection. Finally, the paper offers some recommendations for the external socket connection design based on the test results and the finite element analyses. 


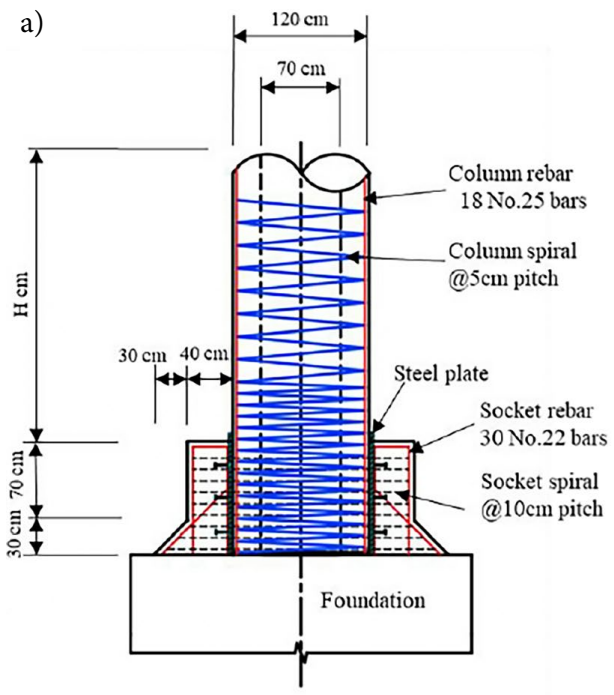

b)

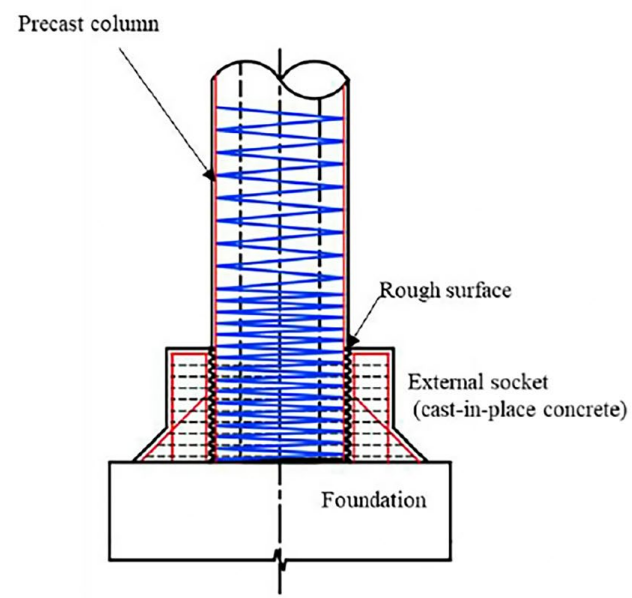

c)

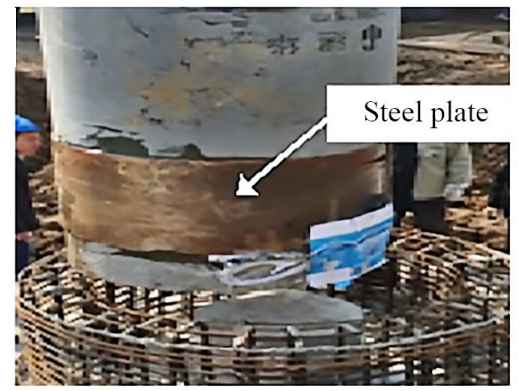

d)

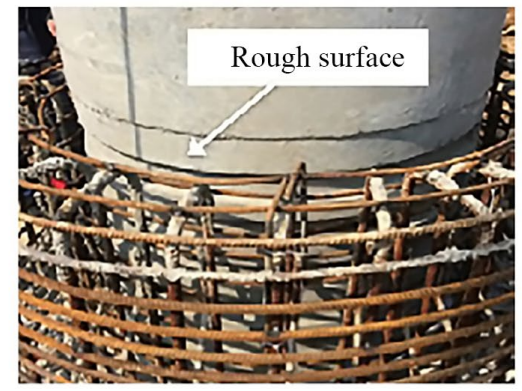

Figure 1. Foundation-column connection: a - Elevation of Type A connection; b - Elevation of Type B connection; c - Photograph of Type A connection; d - Photograph of Type B connection

\section{Background}

The test in this study was developed to validate the connection design used in a project in Anhui Province, China. The bridge project has three or four spans of continuous girder bridges. The three-span bridges are composed of $30+35+30 \mathrm{~m}$ and $3 \times 35 \mathrm{~m}$. The four-span bridges are composed of $4 \times 35 \mathrm{~m}$. The end supports used in this project are those with vertical displacement constraints only. The bridge project also uses interior supports with vertical displacement constraints and horizontal friction constraints. All the columns are precast with a hollow circular section containing an outer diameter measuring 1.2 $\mathrm{m}$ and an inner diameter of $0.7 \mathrm{~m}$. C70 concrete is used for the precast columns, and C50 concrete is used for the socket connection and foundation. All the reinforcements are made from HRB400 with a specified minimum yield stress of 400MPa. Figure 1 shows the elevation of the column and external socket.

Figure 1 shows how the two types of column-foundation connections using external sockets were designed and used in the project. For connection type A, the column is precast with a smooth surface within the external socket, as seen in Figure 1a and Figure 1c. An orientation cap was cast in the center of the foundation to orient the location of column. The reinforcement network of the exter- nal socket was finished before column erection. A mortar layer was added on the foundation surface to adjust the column level. After the column was erected on the foundation, a steel plate was attached to the column as shown in Figure 1c. Finally, the external socket was finished with cast-in-place concrete.

The use of a steel plate in connection type A requires that the steel plate can fully bond with the column, which resulted in a tight tolerance for the steel plate attachment. To improve this, a second column was precast with a rough surface within the external socket instead of the steel plate used in type A, which is categorized as type B and shown in Figure $1 \mathrm{~b}$ and Figure 1d. The erection procedure is similar to that of type A.

The design of these two types assumes that the external socket can fully bond with the column, and the external socket and the column can work together to carry the vertical and horizontal forces and transfer them to the foundation. Actually, the precast column is oriented and put on the foundation first, and then the external socket is cast; the construction sequence may have some effects on the composite work for the column and the external socket. Additionally, the use of a steel plate or rough surface for the force transfer during loading needs to be investigated further to verify the external socket connection behavior. 


\section{Column-foundation connection test specimen design}

The column and column-foundation connection were designed according to JTG D62 specifications (Ministry of Transport of the People's Republic of China, 2004). For a reinforced concrete bridge structure, cracks are allowed, but crack width should be checked for a service limit state of $0.2 \mathrm{~mm}$ (Ministry of Transport of the People's Republic of China, 2004). The critical load for the service limit state is determined from a force analysis of the superstructure. The forces applied to the superstructure include truck loads (including brake force), lane loads, support settlement, linear and nonlinear temperature, brake force, and seismic force. All these forces are combined with load factors (i.e., service limit state and seismic condition in which the load factor for each service limit state term is 1.0) based on design specifications (Ministry of Transport of the People's Republic of China, 2004, 2008) to generate a critical condition to the substructure. Since the columns are located in the low-seismic region, this study uses seismic force E1 (Ministry of Transport of the People's Republic of China, 2004, 2008). In addition, one accidental condition (the rubber-aged condition) is analyzed. This accidental condition assumes that the rubbers at the interior bearings might be aged since the interior bearings use friction rubber supports that partially restrain the longitudinal displacements of the bridge girders. It is not a normal condition during the bridge service life, but it can be treated as a more critical condition (e.g., the maximum capacity condition).

Two test specimens corresponding to the two types of connections (i.e., type A and type B) were designed and analyzed to investigate the behavior of the column-foundation connections and study its mechanisms. To guarantee safety during the specimen erection and stability during the test process, the height of two test specimens is taken as $6 \mathrm{~m}$, which is not corresponding to the tallest one in the project (the maximum height of columns in the project is $12 \mathrm{~m}$ ), but a loading test setup is designed that can model the tallest column's loading condition. As shown in Figures $1 \mathrm{a}$ and $1 \mathrm{~b}$, the depth of the external socket is $100 \mathrm{~cm} .18$ longitudinal No. 25 rebars and spirals with a pitch of $5 \mathrm{~cm}$ are arranged in the precast column; 30 No. 22 rebars and spirals with a pitch of $10 \mathrm{~cm}$ are arranged in the external socket. The test is designed to use two $6 \mathrm{~m}$-height columns and a load test setup that can model any loading conditions for the bridge columns.

\section{Test program}

\subsection{Load}

The seismic force is larger in the columns with a height of $3 \mathrm{~m}$ than that in the columns with a height of $12 \mathrm{~m}$ according to design specifications (Ministry of Transport of the People's Republic of China, 2004, 2008), thus the moment induced at the bottom of the column with $12 \mathrm{~m}$ height doesn't control the design for the seismic condition. Therefore, the conditions included in the paper are found by combining the force analyses of the bridge columns, the service condition and the aged rubber conditions for the column with a height of $12 \mathrm{~m}$. Table 1 lists the maximum forces applied to the top of bridge column from the force analyses of the bridge superstructure.

Table 1. Maximum forces applied to bridge column top

\begin{tabular}{|l|l|c|c|}
\hline \multicolumn{2}{|c|}{ Load condition } & $\begin{array}{c}\text { Horizontal } \\
\text { force }(\mathrm{kN})\end{array}$ & $\begin{array}{c}\text { Vertical } \\
\text { force }(\mathrm{kN})\end{array}$ \\
\hline \multicolumn{2}{|l|}{ Service condition } & 114 & 2880 \\
\hline $\begin{array}{l}\text { Seismic load } \\
\text { under E1 }\end{array}$ & $3 \mathrm{~m}$ column & 422 & - \\
\cline { 2 - 4 } & $12 \mathrm{~m}$ column & 53 & - \\
\hline \multicolumn{2}{|l|}{ Aged rubber condition } & 310 & 2880 \\
\hline
\end{tabular}

\subsection{Test setup}

The test setup is designed to apply vertical and horizontal forces simultaneously, which represents the loads transferred from the superstructure to the top of the column. The forces transferred to the column include both vertical forces (the axial force) and horizontal forces.

As shown in Figure 2, the test setup is composed of three fixtures: (1) a vertical loading cable fixture, (2) an inclined loading cable fixture, and (3) a loading transfer fixture. The vertical loading cable fixture and the inclined loading cable fixture are designed to apply the axial force and horizontal force to the test specimen.

The vertical loading cable fixture applies the axial force to the column. The fixture is composed of two sets of prestressed tendons and jacks arranged under the bottom of the foundation.

The inclined loading cable fixture applies the axial and horizontal force to the test specimen. The fixture is composed of two sets of prestressed tendons and jacks. The jacks were arranged and jacked under the bottom of the foundation adjacent to the tested column. The prestressed tendons are inclined, which applies inclined forces to the test column. The horizontal vector of the forces is equal to the designed applied horizontal force (i.e., the horizontal force transferred from the bridge superstructure to the bridge column), which applies the expected critical moment to the bottom of column. The vertical vector of the forces is added to the axial forces applied by the vertical loading cable fixture equal to that of the designed applied axial force (i.e., the vertical force transferred from the bridge superstructure to the bridge column).

The loading transfer fixture is composed of a loading steel beam and an anchor cap. The loading steel beam is connected to the vertical loading cable fixture while the anchor cap is connected to the inclined loading cable fixture. The loading steel beam applies the axial force from the vertical loading cable fixture to the test specimen. The anchor cap transfers the forces from the inclined loading cable fixture to the test specimen. 


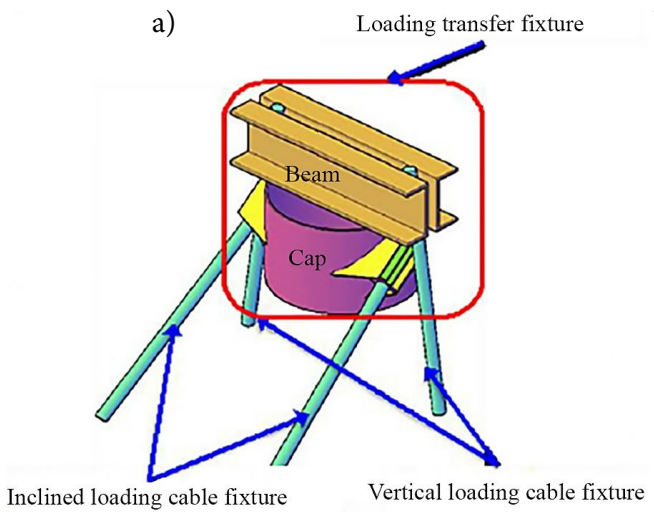

b)

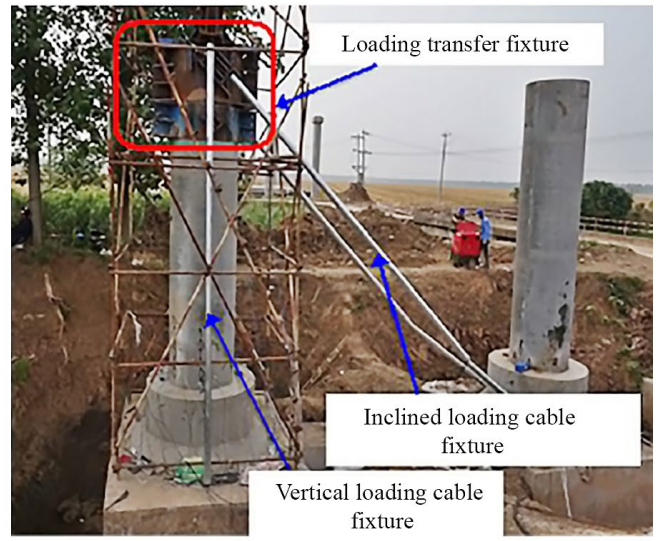

Figure 2. Test setup: $a$ - Test set up composed of three loading fixtures; $b$ - Photograph of loading fixtures

\subsection{Instrumentation}

Strain gages are arranged in the column and columnfoundation connection to measure the strains during the test. As shown in Figure 4, five sections were measured for the column, and three sections were measured for the column-foundation connection (the external socket). Note

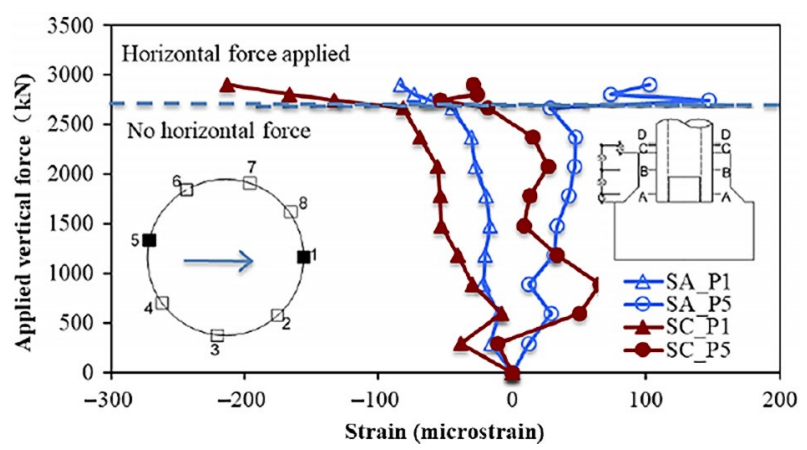

Figure 3. Normal strain versus applied vertical force at Sections $\mathrm{A}$ and $\mathrm{C}$ of column-foundation connection for Type A in Stage 1 that the strain gages were put on the surface of the column at Sections D and E. The planned arrangement of strain gages on connection type $\mathrm{A}$ and $\mathrm{B}$ are a little different depending on the orientation of the specimens. The planned view of each type is shown in the results plots. The lateral displacement of the top of the column was measured by a total station with a precision of $1 \mathrm{~mm}$. Finally, to control the applied forces during the test, the load cells were arranged at the anchor plate of the tendons in the vertical loading cable fixture and the inclined loading cable fixture.

\subsection{Loading plan}

According to the superstructure force analysis, the test considers two loading conditions, which are referred to as Stage 1 and 2. Table 2 and Table 3 present the test's loading plan for both types of connection. An increment load step is used for each stage. Stage 1 models a condition in which the substructure is under service; Stage 2 models a condition in which the substructure is under a possible maximum loading condition where the rubber is aged. a)

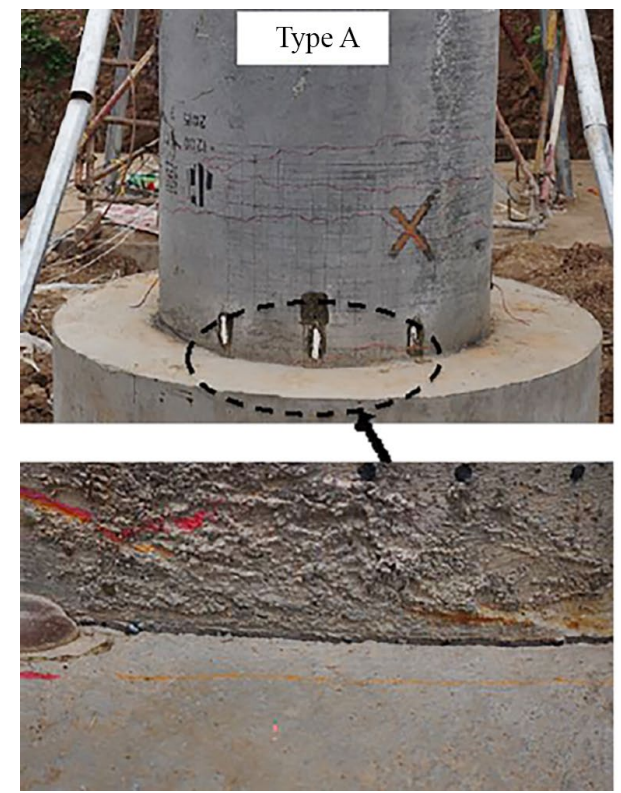

b)

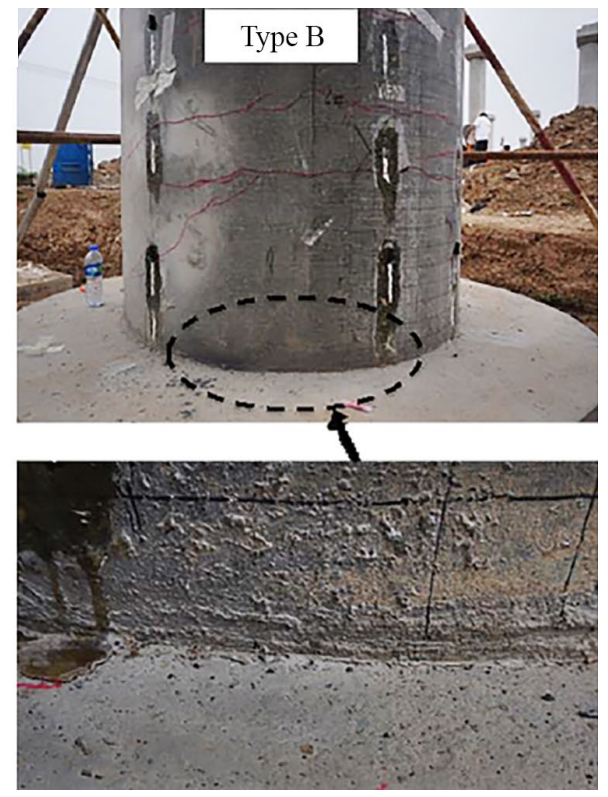

Figure 4. Cracks in column for type A and type B after test: a - Type A; b - Type B 
Table 2. Loading plan for type A connection test

\begin{tabular}{|c|c|c|c|c|c|}
\hline \multirow[b]{2}{*}{ Stage } & \multirow[b]{2}{*}{ Increment } & \multicolumn{2}{|c|}{$\begin{array}{l}\text { Forces in loading } \\
\text { fixture }\end{array}$} & \multicolumn{2}{|c|}{$\begin{array}{l}\text { Equilibrium forces } \\
\text { applied to column }\end{array}$} \\
\hline & & $\begin{array}{c}\text { Vertical } \\
\text { loading } \\
\text { cable } \\
(\mathrm{kN})\end{array}$ & $\begin{array}{c}\text { Inclined } \\
\text { loading } \\
\text { cable } \\
(\mathrm{kN})\end{array}$ & $\begin{array}{c}\text { Vertical } \\
\text { force } \\
(\mathrm{kN})\end{array}$ & $\begin{array}{l}\text { Horizontal } \\
\text { force } \\
(\mathrm{kN})\end{array}$ \\
\hline \multirow{9}{*}{1} & $1-1$ & 0 & 0 & 0 & 0 \\
\hline & $1-2$ & 300 & 0 & 594 & 0 \\
\hline & $1-3$ & 600 & 0 & 1188 & 0 \\
\hline & $1-4$ & 900 & 0 & 1782 & 0 \\
\hline & $1-5$ & 1200 & 0 & 2376 & 0 \\
\hline & $1-6$ & 1350 & 0 & 2673 & 0 \\
\hline & $1-7$ & 1355 & 50 & 2746 & 77 \\
\hline & $1-8$ & 1355 & 100 & 2810 & 153 \\
\hline & $1-9$ & 1355 & 177 & 2908 & 271 \\
\hline \multirow{10}{*}{2} & $2-1$ & 1200 & 0 & 2376 & 0 \\
\hline & $2-2$ & 1350 & 100 & 2800 & 153 \\
\hline & $2-3$ & 1350 & 175 & 2896 & 268 \\
\hline & $2-4$ & 1300 & 225 & 2860 & 345 \\
\hline & $2-5$ & 1275 & 275 & 2875 & 422 \\
\hline & $2-6$ & 1175 & 425 & 2868 & 652 \\
\hline & $2-7$ & 1145 & 482 & 2881 & 739 \\
\hline & $2-8$ & 1145 & 180 & 2496 & 276 \\
\hline & $2-9$ & 1145 & 330 & 2687 & 506 \\
\hline & $2-10$ & 1145 & 480 & 2878 & 736 \\
\hline
\end{tabular}

Table 3. Loading plan for type B connection test

\begin{tabular}{|c|c|c|c|c|c|}
\hline \multirow[b]{2}{*}{ Stage } & \multirow[b]{2}{*}{ Increment } & \multicolumn{2}{|c|}{$\begin{array}{l}\text { Forces in loading } \\
\text { fixture }\end{array}$} & \multicolumn{2}{|c|}{$\begin{array}{l}\text { Equilibrium forces } \\
\text { applied to column }\end{array}$} \\
\hline & & $\begin{array}{c}\text { Vertical } \\
\text { loading } \\
\text { cable } \\
(\mathrm{kN})\end{array}$ & $\begin{array}{c}\text { Inclined } \\
\text { loading } \\
\text { cable } \\
(\mathrm{kN})\end{array}$ & $\begin{array}{l}\text { Vertical } \\
\text { force } \\
(\mathrm{kN})\end{array}$ & $\begin{array}{l}\text { Horizontal } \\
\text { force } \\
(\mathrm{kN})\end{array}$ \\
\hline \multirow{10}{*}{1} & $1-1$ & 0 & 0 & 0 & 0 \\
\hline & $1-2$ & 350 & 0 & 693 & 0 \\
\hline & $1-3$ & 700 & 0 & 1386 & 0 \\
\hline & $1-4$ & 1050 & 0 & 2079 & 0 \\
\hline & $1-5$ & 1402 & 0 & 2776 & 0 \\
\hline & $1-6$ & 1402 & 35 & 2820 & 54 \\
\hline & $1-7$ & 1402 & 70 & 2865 & 107 \\
\hline & $1-8$ & 1350 & 101 & 2801 & 155 \\
\hline & $1-9$ & 1350 & 135 & 2845 & 207 \\
\hline & $1-10$ & 1350 & 177 & 2898 & 271 \\
\hline \multirow{9}{*}{2} & $2-1$ & 0 & 0 & 0 & 0 \\
\hline & $2-2$ & 1350 & 75 & 2768 & 115 \\
\hline & $2-3$ & 1350 & 150 & 2864 & 230 \\
\hline & $2-4$ & 1300 & 225 & 2860 & 345 \\
\hline & $2-5$ & 1250 & 300 & 2857 & 460 \\
\hline & $2-6$ & 1200 & 375 & 2853 & 575 \\
\hline & $2-7$ & 1150 & 450 & 2850 & 690 \\
\hline & $2-8$ & 1145 & 482 & 2881 & 739 \\
\hline & $2-9$ & 1145 & 510 & 2916 & 782 \\
\hline
\end{tabular}

The elastic loading condition limit corresponds to the service limit state. The service limit state models a state in which the column works under a critical load combination during its service time, as required by the design. Altogether, this test checks the safety and behavior of the column-foundation connection using external socket.

The inelastic loading condition limit corresponds to the applied horizontal force limit, which models a state in which the intermediate friction rubber supports have aged. This state is a critical condition for the column and the connection, and can serve as a representation of the maximum load capacity condition.

\section{Experimental results}

During the test, the strains and displacement at the top of the column are measured along with the load increase. Then, the relationship of load-strain and load-displacement from the test data are plotted to investigate the behavior of the column and the external socket connection.

\subsection{Connection Type A test results}

\section{Stage 1}

Stage 1 applies forces to the specimen and models the column works under the service condition. No cracks were observed. Figure 3 presents normal strain versus applied axial force in Stage 1. In the figures, the negative value denotes compression strain while the positive value denotes tension strain. The strains at positions 1 and 5 increase along with the applied vertical force increase. In the figure, SA_P1 and SA_P5 refer to the strain measurement points 1 and 5 in Section A, respectively. SC_P1 and SC_P5 refer to the strain measurement points 1 and 5 in Section $C$, respectively. The strains at position 5 decrease after the horizontal force is applied, but these values are small. The maximum compressive strain is about 220 microstrain, which occurs at position 1 of Section $\mathrm{C}$, and there is no yielding for the concrete (the yield strength of concrete is about 1900 microstrain). The compressive strain in Section A is smaller than that in Section C. If the column and column-foundation connection fully contact each other, the compressive strain at section A should be larger than that in section C. Here the results are reversed, however. One possible explanation is that the column is not fully constrained with the connection, which will be discussed later.

In Stage 1, the lateral displacement was measured at the top of the column. The value is small, with a maximum measured value less than $2 \mathrm{~mm}$. No cracks were observed in Stage 1. The test results in Stage 1 show that the column and column-foundation satisfy the service limit requirements.

\section{Stage 2}

Cracks were observed and recorded during Stage 2. The first notable crack was observed when the horizontally applied force was $422 \mathrm{kN}$. The cracks propagated quickly 
as the horizontal force increased. When the applied horizontal force was up to $782 \mathrm{kN}$, the cracks grew up to twothird of the column diameter. Figure 4a shows a photo of the cracks after the test was completed. A gap was clearly visible between the connection and column.

Figure 5 compares normal strain to the applied axial force in the column and column-foundation connection in Stage 2. Before the horizontal force applied, the strains are small for both section $\mathrm{A}$ and section $\mathrm{D}$, which are less than 100 microstrain. In the figure, SD_P1 and SA_P5 refer to the strain measurement point 1 and point 5 in Section $\mathrm{D}$, respectively. The strain at position 1 increases along with the horizontal force increase while the strain at position 5 decreases due to the moment induced by the applied horizontal force. This pattern holds true for both sections in the column and the connection.

As shown in Figure 5a, column strains in Section A are much less than that in Section D, since the column works with the connection to carry the forces at Section A. The maximum compressive strain at position 1 of Section $\mathrm{D}$ is larger than 1000 microstrain, but even that does not reach the compressive yield strength of concrete. The maximum tensile strain, on the other hand, is larger than $150 \mathrm{mi}-$ crostrain. Since the tensile yield strength of concrete is about 110 microstrain, this measure indicates that some cracks occur in the column.

For the connection shown in Figure 5b, the strains at Section A do not vary much. For Section C, the strains at position 5 are not that large, but the strains at position 1 vary greatly as the applied horizontal force increases. The maximum compressive strain is about 1000 microstrain.

a)

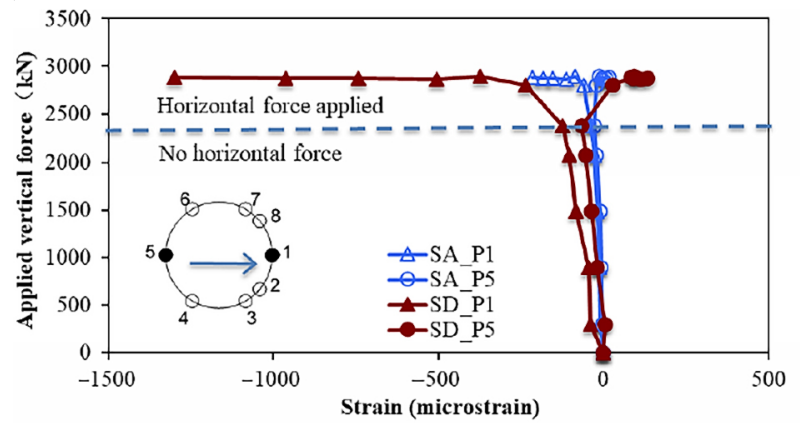

b)

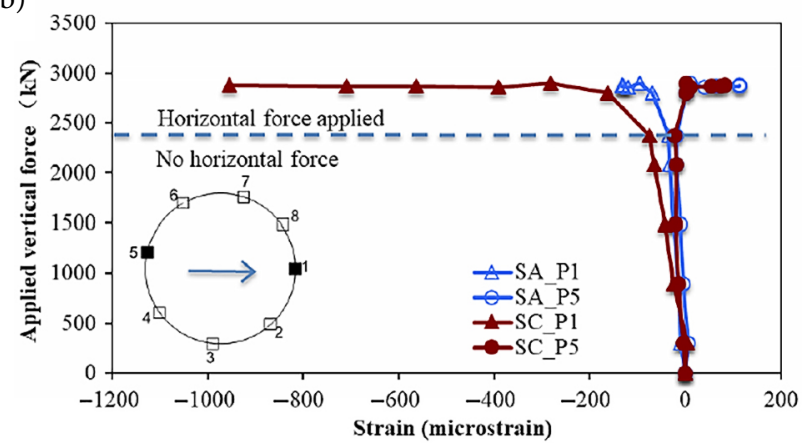

Figure 5. Normal strain versus applied vertical force for Type A in Stage 2: $\mathrm{a}$ - At Sections A and D of column; b - At Sections $\mathrm{A}$ and $\mathrm{C}$ of column-foundation connection
The external socket was expected to work with the column to carry the applied force at Section $\mathrm{C}$ resulting in strains at section $\mathrm{C}$ being less than those at section $\mathrm{A}$. The reason for this variance will be discussed later.

Figure 6 compares the lateral displacement at the top of the column to the applied horizontal force in Stage 2. When the applied horizontal force is small, the displacement is also small. The displacement increases as the applied horizontal force increases. A linear relationship is visible when the applied horizontal force is smaller than $300 \mathrm{kN}$. After that, when the applied horizontal force increases, the displacement increases at a faster rate. The maximum horizontal displacement is $0.08 \mathrm{~m}$.

Figure $7 \mathrm{a}$ presents the normal strain to the column and connection while the vertical force is applied. The results show that the connection works with the column to carry the applied force. The results also show that the

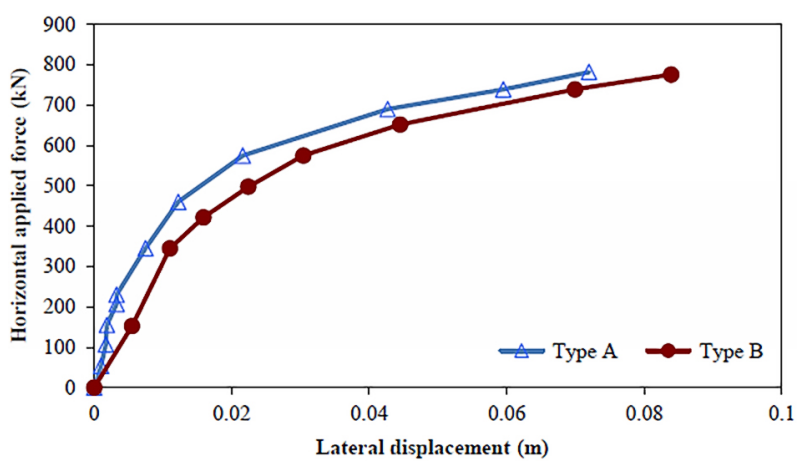

Figure 6. Lateral displacement versus applied horizontal applied force at top of column during loading in Stage 2

a)

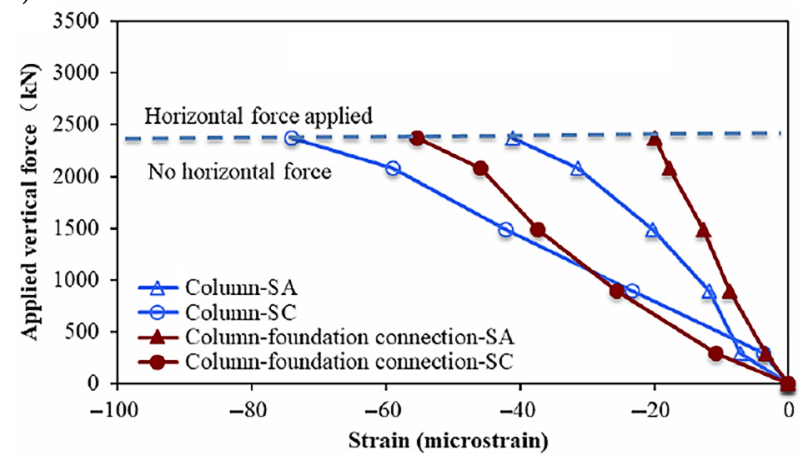

b)

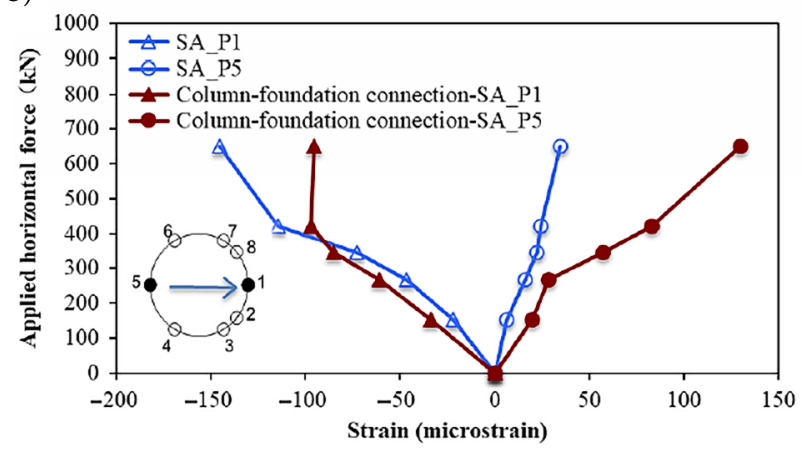

Figure 7. Normal strain in the column and column-foundation connection for Type A in Stage 2: a - During the processes of vertical force applied; $b$ - During the processes of horizontal force applied 
compressive strain for the column in section $\mathrm{C}$ is larger than that in Section A, which indicates that the vertical force is transferred from the column to the socket connection. But there are big differences between Section A and Section $\mathrm{C}$ concerning the socket connection (55 microstrain in Section C, while only about 18 microstrain in Section A), which means the vertical force transfer is not uniform across all socket connections.

Figure $7 \mathrm{~b}$ presents the normal strain in the column and the column-foundation connection at section A caused by the applied horizontal force. The strains shown in the figure are only induced by the applied horizontal force, not the total force. The results show that there is a linear relationship between the normal strain and the applied horizontal force when the applied horizontal force is less than $300 \mathrm{kN}$. When the applied horizontal force is larger, the strains at position 5 increase for both the column and the column-foundation connection, but the strains at position 1 in the column-foundation connection have almost no change (around 100 microstrain) and is less than the strains in the column at position 1 when the applied force is large. This indicates that the external socket connection doesn't fully constrain the column at position 1 .

Combining the results from Figure 4, Figure 7, and the gap observed in Figure 4a, one can conclude that the column is not fully in contact with the column-foundation connection. As a result, the constraint between the column and the connection is not consistent with the initial design (which involved a fully bonded constraint), since the column-foundation connection doesn't fully constrain the column. Therefore, the external socket is only partially in contact with the column, which is especially true after horizontal force is applied.

\subsection{Connection Type B test results}

\section{Stage 1}

Figure 8 compares the normal strain to the applied axial force in the Stage 1 column-foundation connection. The strains at position 1 in Section A increase as the applied horizontal force increases. The strains at position 5 in Section A and Section C vary from compression to tension with the increase in applied horizontal force, but the strains are small due to the cross-section changes within the socket. These observations indicate that the connection works well with the column.

In Stage 1, the lateral displacement was measured at the top of the column. The value is small, with a maximum measured value less than $2 \mathrm{~mm}$. No cracks were observed during Stage 1 loading. The test results for Stage 1 show that the column-foundation and the column satisfy the service limit requirements.

\section{Stage 2}

Cracks were observed and recorded during Stage 2, however. The first crack was observed when the applied horizontal force was $460 \mathrm{kN}$. The cracks propagated quickly as the applied horizontal force increased. When the applied horizontal force reached $782 \mathrm{kN}$, the cracks grew to twothird of the column diameter. Figure $4 \mathrm{~b}$ shows the cracks after the test was completed.

Figures $9 \mathrm{a}$ and $9 \mathrm{~b}$ compare the normal strain to the applied axial force in the column and the column-foundation connection in Stage 2. Since the cross-section changes within the socket for the column shown in Figure 9a, the strains at Section A are small, with a maximum compressive strain of about 200 microstrain, and a maximum tensile strain of less than 100 microstrain. For Section D, the maximum compressive strain is about 1300 when the maximum horizontal force is applied while the maximum tensile strain is over 500 microstrain. Since the tensile yield strength of concrete is about 110 microstrain, these results indicate some cracks occurred, which were visible in this study.

As shown in Figure 9b, the connection strains in Section A are small, with a maximum compressive strain of

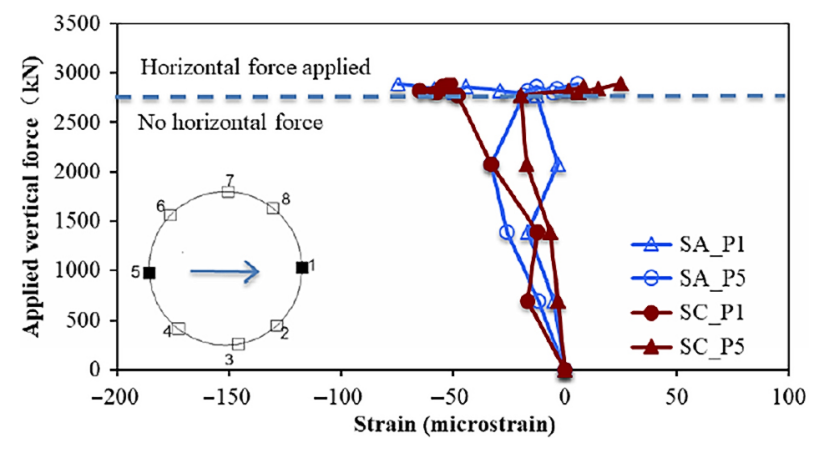

Figure 8. Normal stress versus applied vertical force for Type B in Stage 1

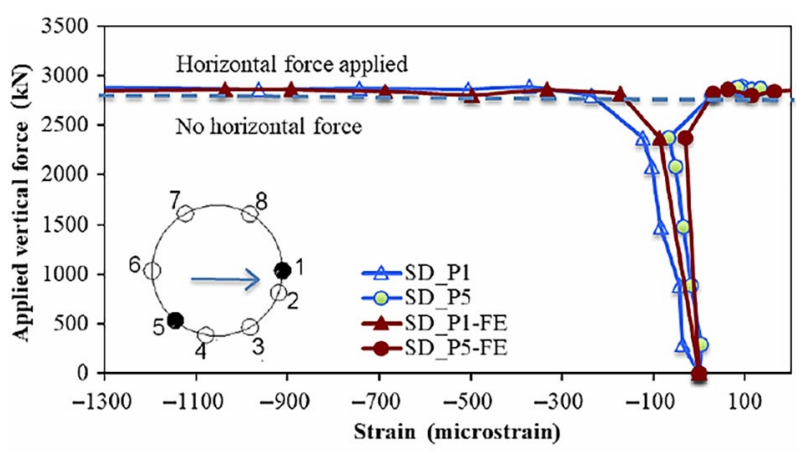

b)

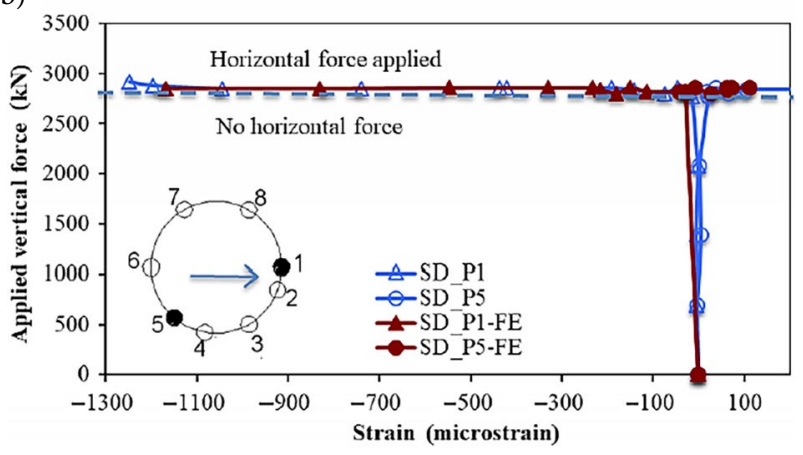

Figure 9. Normal stress versus applied horizontal applied force in column at Section D in Stage 2: a - Type A; b - Type B 
75 microstrain, and a tensile strain of less than $100 \mathrm{mi}-$ crostrain. The strains in section $\mathrm{C}$ are smaller than those in section A since the moment at section A is larger than that at section $\mathrm{C}$ from the system's load static calculation. When combined with the results of the Section A column, this indicates that the constraint between the column and connection works well.

Figure 6 also compares the lateral displacement at the column top to the applied horizontal force for type B. When the applied horizontal force is small, the displacement is also small. The displacement increases as the applied horizontal force increases. A linear relationship is visible while the applied horizontal force remains less than $300 \mathrm{kN}$. After that, the displacement increases quickly as the applied horizontal force increases. The maximum horizontal displacement is $0.072 \mathrm{~m}$.

Figure 10a shows the normal strains as the axial force is applied to the column and column-foundation connection. The strains in section A are larger than those in section $\mathrm{C}$ since the moment in section $\mathrm{A}$ is larger than the static load calculation. The strains in the column are larger than those in the connection, however, which indicates that the connection only partially works to carry the applied axial force. Comparing the strains in Section A and Section C, the vertical force transferred to the socket connection is about 0.25 of the total vertical force, indicating that the friction ratio between the column and the socket connection is 0.25 .

Figure $10 \mathrm{~b}$ presents the normal strains in the section A column and column-foundation connection due to the

a)

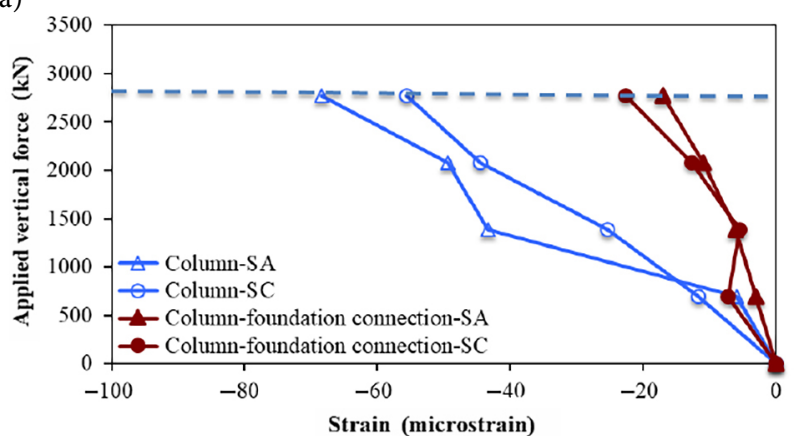

b)

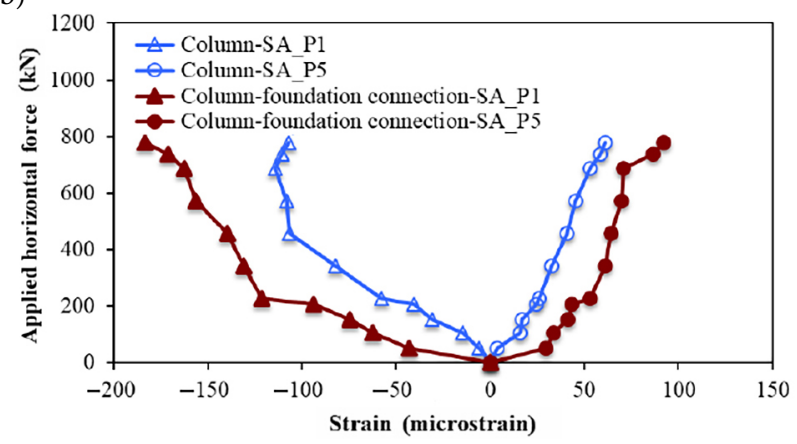

Figure 10. Normal strain in column and column-foundation connection for Type B in Stage 2: a - During the processes of vertical force applied; $b$ - During the processes of horizontal force applied applied horizontal force. The strains shown in this figure are only induced by the applied horizontal force, not the total force. The results show that the strains in the connection at position 1 and position 5 are larger than those in the connection, and the strains increase as the applied force increases. The results show that the connection and the column can effectively work together to carry the applied horizontal force.

\subsection{Comparisons}

The test results of these two connection types satisfy the service condition requirements. These two connections, however, are different in certain aspects, especially considering the stress distribution in the connection. As seen in the observations from Figures 4 and 10, the strains in the connection type B vary slightly as the applied horizontal force increases. For type A, however, the compressive strains at position 1 of Section $C$ are much larger, with a maximum strain of as much as 1000 microstrain. The reason for this is that the connection type A cannot fully bond with the column and there are observable gaps between the column and connection. At the same time, the type B connection results in a much better constraint condition between the column and the connection.

For the lateral displacement at the top of the column, the results shown in Figures 6 reveal that the lateral displacement of connection type $A$ is larger than that of connection type $B$ under the same applied horizontal force.

As shown in Figure 4, the cracks propagated through two-third of the column diameter after the maximum horizontal force was applied. An obvious gap was observed between the connection and the column for connection type A, while a small crack was observed for connection type B. Considered alongside the strain distribution comparisons in the Section C connection, these results indicate that connection type A cannot fully bond with the column. Ultimately, connection type B works better to supply a good constraint between the connection and the column.

\section{Finite element analysis}

\subsection{Finite element model}

This study used ABAQUS software (version 6.14) to develop a finite element (FE) analysis. Solid elements (type C3D8) were used to model the column and the columnfoundation connection. Truss elements (type T3D2) were used to model reinforcements. Different mesh sizes were used to reduce computation time. The mesh size $4 \mathrm{~m}$ from the column top was larger $(0.1 \mathrm{~m})$, while the rest of the analysis relied on a smaller mesh size $(0.05 \mathrm{~m})$.

The precast column is made of C70 concrete with a density of $2500 \mathrm{~kg} / \mathrm{m}^{3}$, a Young's modulus of $37 \mathrm{GPa}$, and a Poisson ratio of 0.2 . The column-foundation connection is made of C50 concrete with a density of $2500 \mathrm{~kg} / \mathrm{m}^{3}$, a Young's modulus of $34.5 \mathrm{GPa}$, and a Poisson ratio of 0.2. 
The analysis uses a brittle concrete cracking model that can adequately simulate the flexure, flexure-shear, and direct shear failure of a reinforced concrete (RC) structure (Shi et al., 2018; Xia et al., 2017).

Since there was a gap between the connection and the column, a "contact" constraint was used to model the condition between the connection and the column in connection type A. The gap assumption is based on the crack observation in the test revealing that there was a small gap between the connection and the column. A "rigid" constraint was used to model the relation between the connection and the column for connection type B. The model applies simple supported boundary conditions. The lateral and vertical displacements were restrained for the nodes at the bottom of the connection as well as those at the bottom of the column.

The loads applied in the model correspond to the loads in the test for each type of connection. The loads during the test are applied by the test setup, which applies both a vertical and horizontal force at the top of the column. In the FE model, the vertical and horizontal forces are applied directly at the top of the column. The strains and displacement in Stages 1 are not large. The analyses for Stage 2 are presented elsewhere in this paper.

\subsection{Comparison between test results and FE results}

\section{Connection Type A comparisons}

Figure 11a compares the lateral displacement at the top of the column to the applied horizontal force for the test results and the FE results. Up to the applied horizontal force of $580 \mathrm{kN}$, the FE results agree with the test results. The FE model has a smaller maximum load capacity as the test results. One possible reason is that a pair of vertical prestressed tendons was used to apply the vertical forces and may have had some effect when the lateral displacement is larger. Another reason is that the spiral reinforcements are not included in the model. The FE results for a cast-in-place column are presented in the figure. In the elastic range, the lateral displacement of the cast-in-place column is less than that of type A, which is due to the gap between the column surface and the socket. But the capacity of the cast-in-place column is less than that of type A, which shows that the socket connection shifts the plastic hinge of the column.

Figure 12a compares the normal strains to the applied axial force for the test results and the FE results in the Section D column and in the Section C connection. The results show that the FE model matches the test data well, suggesting that connection type A cannot fully constrain the column because there is a gap between the column and the connection.

\section{Connection Type B comparisons}

Figure $11 \mathrm{~b}$ compares the lateral displacement at the top of the column to the applied horizontal force for test results and FE results. Up to a horizontal force of $580 \mathrm{kN}$, the FE results agree with the test results; however, the FE model has a smaller ultimate load capacity than the results imply. Connection type B has less displacement than the cast-in-place concrete under the same load, indicating that connection type B can be fully bound to the column. In addition, the capacity of type $B$ is larger than that of the

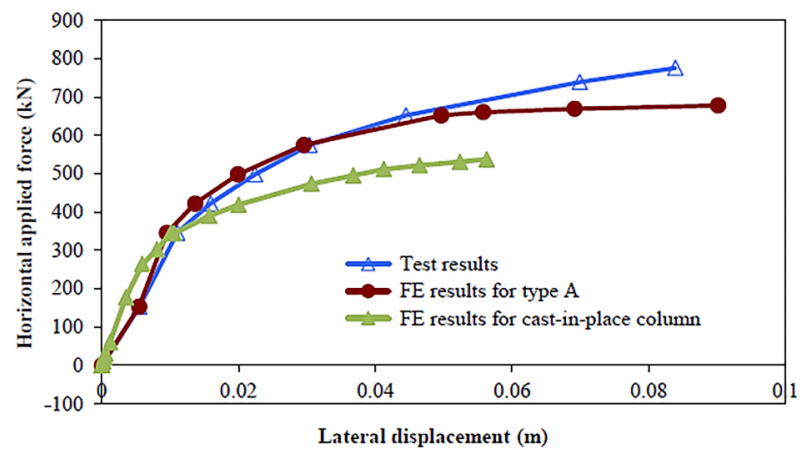

b)

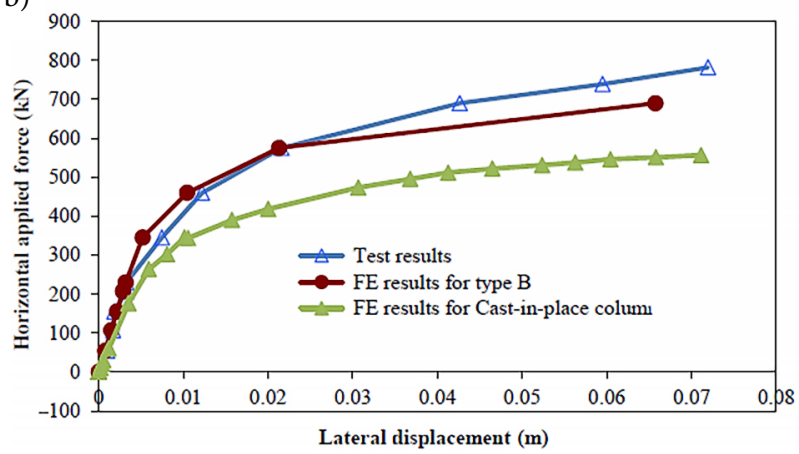

Figure 11. Lateral displacement versus horizontal applied force: a - Type A; b - Type B

a)

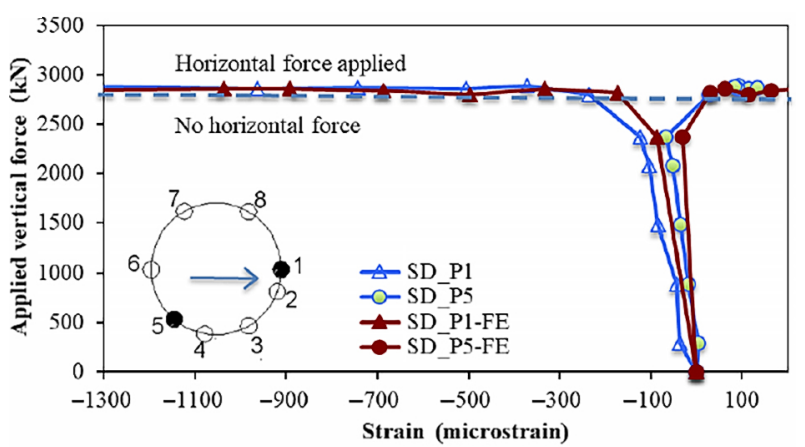

b)

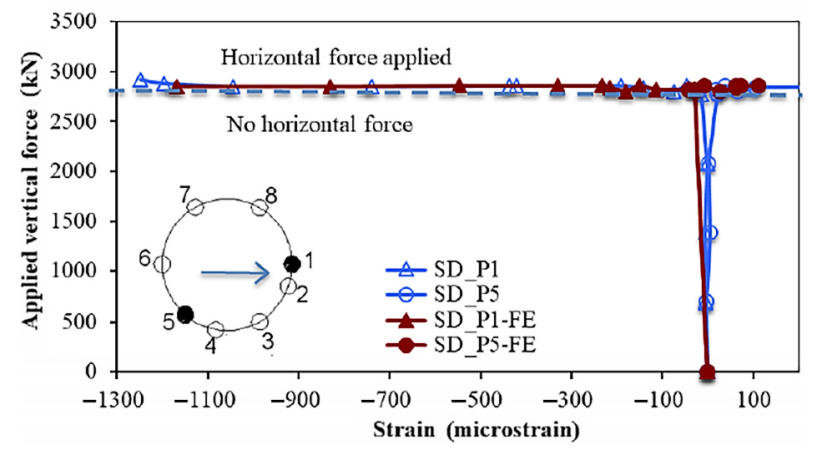

Figure 12. Normal stress versus applied horizontal applied force in column at Section D in Stage 2: a - Type A; b - Type B 
cast-in-place column, which shows that the socket connection shifts the plastic hinge of the column. Figure $12 \mathrm{~b}$ compares the normal strains to the applied axial force for the test results and FE results for the Section D column. Figure 13 compares the crack propagation between the FE analysis and the test data. The results indicate that the FE results and the test data are in strong agreement, and the plastic hinge occurs in the column above the socket connection with no failure in the socket.

\subsection{Design check}

The analyses above focus on the test specimen but the actual height of the project columns is up to $12 \mathrm{~m}$. Thus, the FE analysis must be extended to investigate the behavior of $12 \mathrm{~m}$ columns using both connection types. Figure 14 presents the load-displacement curves for various depths of connection socket. For type A, the capacity of the column-foundation connection increases as the socket depth increases and the corresponding lateral displacement decreases. Thus, the increase of socket depth is efficient at improving the behavior of connection type A. For connection type $\mathrm{B}$, the load-displacement curves are similar for various socket depths, implying that the socket depth has little effect on the behavior of connection type B.

From the test data and FE analysis above, connection type B can guarantee that the column-foundation connection will fully constrain the column. The results also suggest using connection type B to connect the precast column and foundation as well as reducing the use of the steel plates and shear studs on-site. Furthermore, the data shows that the connection does not fully work with the column to carry the vertical forces, but it does work well with regards to carrying the horizontal force. Some observation and simplified calculation recommendations for the design is proposed to account for the forces distributed in the column and connection, including: (1) for type $B$ with rough surface, the friction ratio between the column and the socket connection can be taken as 0.25 for the socket with a depth of $1 \mathrm{~m}$; (2) the moment induced by the horizontal force can be fully carried by the connection and column within the socket; and (3) increasing the socket depth for type A can improve the behavior of the socket connection. Additionally, the comparison between the FE results and the test data indicate that the FE model can be used to further design this external socket connection and continue to study the dynamic behavior of the system.

\section{Conclusions}

Systematic experimental tests and FE analysis were conducted to investigate the similarities and differences in structural performance regarding two types of connection design. Similarities in their behavior suggested from comprehensive investigation results are summarized as follows:

- The stresses and lateral displacements are small when the load is applied to the service condition, mean- a)

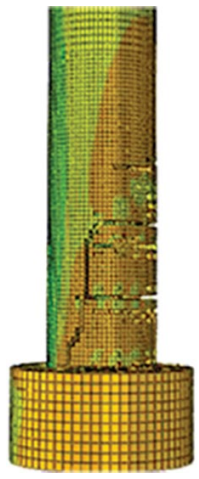

b)

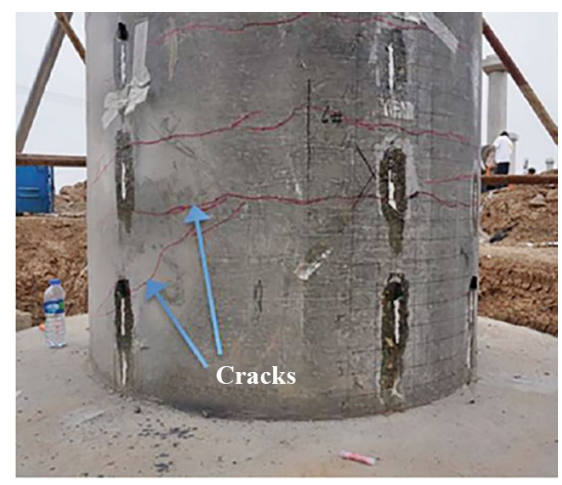

Figure 13. Cracks after column fails: a - FE results; $\mathrm{b}-$ Test results

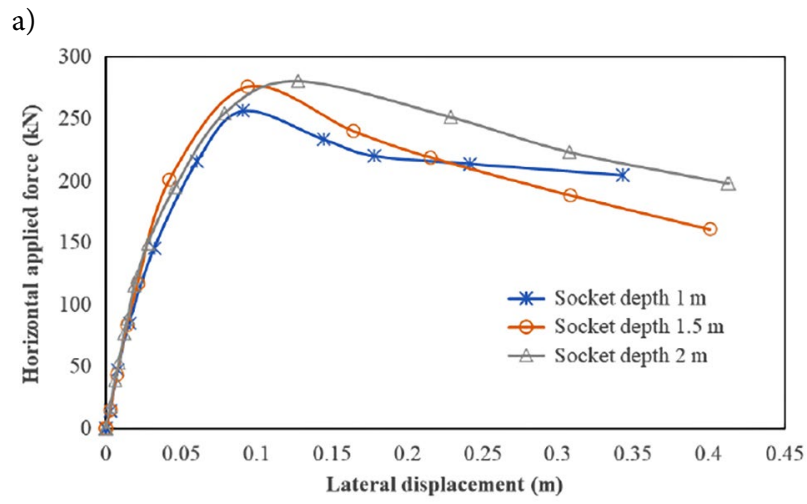

b)

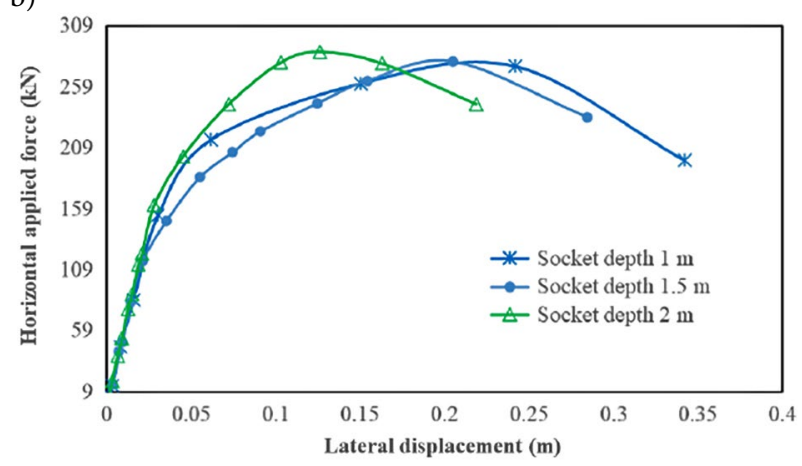

Figure 14. Lateral displacement versus applied horizontal applied force at top of column for $12 \mathrm{~m}$-height column:

a - Type A; b - Type B

ing that the design satisfies the requirements of the service condition;

- When the maximum horizontal force for the service condition was applied, the column-foundation connection has no obvious cracks for either of the two connection types;

- The column-foundation works together to resist the vertical and horizontal force;

- When the maximum horizontal force (Stage 2) was applied, significant cracks were observed, measuring up to two-third of the column diameter, resulting in column failure before the connection;

- The column fails before the connection fails and the 
plastic hinge occurs in the column; thus, the design of column-foundation connection satisfies the requirements and can be used safely to connect precast columns and foundations in low-seismic regions.

Differences between the two connection types are summarized as follows:

- Under the same load, the lateral displacement for connection type $\mathrm{B}$ is smaller than that of connection type A;

- Connection type A has is a local effect in which the corner of the connection experiences a large, locally compressive stress;

- When the maximum horizontal force was applied, an obvious gap was found for connection type A where the connection and the column connected, while only a small crack was found for connection type B;

- The test results and the FE results indicate that connection type A cannot fully constrain the column, while connection type B can guarantee a full constrain between the column and the connection; furthermore, the socket depth has some effect on the behavior of type A, but little effect on type B;

- The finite element model results are consistent with the test results, and shows a smaller ultimate capacity than the test results. Therefore, the finite element models can be used to safely design and investigate the behavior of column-foundation connections, especially for the connection type B design.

These tests were conducted to investigate the behavior of the connection under the service conditions, and further study is needed to investigate the dynamic and ductility of the connection to improve the external socket connection design.

\section{Acknowledgements}

Research funding provided by the National key research and development program of China (Grant No. 2017YFC1500603), and Science and Technology Commission of Shanghai Municipality (Grant No. 18DZ1201203) is greatly acknowledged.

\section{Declaration of competing interest}

The authors declare that they have no conflict of interest.

\section{References}

Belleri, A., \& Riva, P. (2012). Seismic performance and retrofit of precast concrete grouted sleeve connections. PCI Journal, 57(1), 97-109. https://doi.org/10.15554/pcij.01012012.97.109

Billington, S. L., Barnes, R. W., \& Breen, J. E. (1999). A precast segmental substructure system for standard bridges. PCI Journal, 44(4), 56-73. https://doi.org/10.15554/pcij.07011999.56.73

Cai, Z. K., Wang, Z. Y., \& Yang, T. Y. (2018). Experimental testing and modeling of precast segmental bridge columns with hybrid normal- and high-strength steel rebars. Construction and Building Materials, 166, 945-955.

https://doi.org/10.1016/j.conbuildmat.2018.01.159

Canha, R. M. F., Campos, G. M., \& El Debs, M. K. (2012). Design model and recommendations of column-foundation connection through socket with rough interfaces. Revista IBRACON de Estruturas e Materiais, 5(2), 182-218.

https://doi.org/10.1590/S1983-41952012000200005

Cheng, Z., \& Sritharan, S. (2019). Side shear strength of preformed socket connections suitable for vertical precast members. Journal of Bridge Engineering, 24(5), 04019025.

https://doi.org/10.1061/(ASCE)BE.1943-5592.0001391

Cheng, Z., \& Sritharan, S. (2020). Outdoor test of a prefabricated column-pile cap-pile system under combined vertical and lateral loads. Journal of Bridge Engineering, 25(8), 04020052. https://doi.org/10.1061/(ASCE)BE.1943-5592.0001588

Do, T. V., Pham, T. M., \& Hao, H. (2018). Numerical investigation of the behavior of precast concrete segmental columns subjected to vehicle collision. Engineering Structures, 156, 375-393. https://doi.org/10.1016/j.engstruct.2017.11.033

Hewes, J. T. (2013). Analysis of the state of the art of precast concrete bridge substructure systems (Final report 687). Arizona Department of Transportation Research Center.

Hung, H.-H., Sung, Y.-C., Lin, K.-C., Jiang, C.-R., \& Chang, K.-C. (2017). Experimental study and numerical simulation of precast segmental bridge columns with semi-rigid connections. Engineering Structures, 136, 12-25. https://doi.org/10.1016/j.engstruct.2017.01.012

Li, C., Hao, H., \& Bi, K. M. (2017a). Numerical study on the seismic performance of precast segmental concrete columns under cyclic loading. Engineering Structures, 148, 373-386. https://doi.org/10.1016/j.engstruct.2017.06.062

Li, J., Wu, C. Q., Hao, H., \& Liu, Z. X. (2017b). Post-blast capacity of ultra-high performance concrete columns. Engineering Structures, 134, 289-302.

https://doi.org/10.1016/j.engstruct.2016.12.057

Li, T., Qu, H., Wang, Z., Wei, H., \& Jiang, S. (2018). Seismic performance of precast concrete bridge columns with quasistatic cyclic shear test for high seismic zones. Engineering Structures, 166, 441-453.

https://doi.org/10.1016/j.engstruct.2018.03.086

Marsh, M. L., Wernli, M., Garrett, B. E., Stanton, J. F., \& Eberhard, M. O. (2011). Application of accelerated bridge construction connections in moderate-to-high seismic regions (NCHRP report, Vol. 698). Transportation Research Board. https://doi.org/10.17226/14571

Ministry of Transport of the People's Republic of China. (2004). China general specifications for design of highway bridges and culverts (JTG D60-2004).

Ministry of Transport of the People's Republic of China. (2008). Guidelines for seismic design of highway bridges (JTG/T B0201-2008).

Nguyen, W., Trono, W., Panagiotou, M., \& Ostertag, C. P. (2017). Seismic response of a rocking bridge column using a precast hybrid fiber-reinforced concrete (HyFRC) tube. Composite Structures, 174, 252-262.

https://doi.org/10.1016/j.compstruct.2017.04.058

Shi, X., Cao, Z., Ma, H., \& Ruan, X. (2018). Failure analysis on a curved girder bridge collapse under eccentric heavy vehicles using explicit finite element method: Case study. Journal of Bridge Engineering, 23(3), 05018001.

https://doi.org/10.1061/(ASCE)BE.1943-5592.0001201 
Tazarv, M., \& Saiidi, M. S. (2015). Design and construction of precast bent caps with pocket connections for high seismic regions (Report No. CCEER-15-06). Center for Civil Engineering Earthquake Research, Department of Civil and Environmental Engineering, University of Nevada, Reno, Nevada.

Tran, H. V. (2015). Drilled shaft socket connections for precast columns in seismic regions [PhD Dissertation]. University of Washington, USA.

Wang, Z., Qu, Q., Li, T., Wei, H., Wang, H., Duan, H., \& Jiang, H. (2018). Quasi-static cyclic tests of precast bridge columns with different connection details for high seismic zones. Engineering Structures, 158, 13-27.

https://doi.org/10.1016/j.engstruct.2017.12.035

Wang, Z., Li, T., Qu, H., Wei, H., \& Li, Y. (2019). Seismic performance of precast bridge columns with socket and pocket connections based on quasi-static cyclic tests: Experimental and numerical study. Journal of Bridge Engineering, 24(11), 04019105.

https://doi.org/10.1061/(ASCE)BE.1943-5592.0001463

Xia, Y., Nassif, H., \& Su, D. (2017). Early-age cracking in high performance concrete decks of typical curved steel girder bridges. Journal of Aerospace Engineering, 30(2), B4016003. https://doi.org/10.1061/(ASCE)AS.1943-5525.0000595

Xia, Y., Wang, P., \& Sun, L. M. (2019). Neutral axis-based health monitoring and condition assessment techniques for concrete box girder bridges. International Journal of Structural Stability and Dynamics, 23(4), 1940015. https://doi.org/10.1142/S0219455419400157

Yan, Q., Chen, T., \& Xie, Z. (2018). Seismic experimental study on a precast concrete beam-column connection with grout sleeves. Engineering Structures, 155, 330-344. https://doi.org/10.1016/j.engstruct.2017.09.027

Zhao, L., Bi, K., M., Hao, H., \& Li, X. (2017). Numerical studies on the seismic responses of bridge structures with precast segmental columns. Engineering Structures, 151, 568-583. https://doi.org/10.1016/j.engstruct.2017.08.018 